\title{
Analisa Postur Kerja Manual Material Handling (MMH) pada Karyawan Bagian Pembuatan Block Menggunakan Metode Rapid Upper Limb Assessment (RULA) (Studi Kasus: PT Asia Forestama Raya)
}

\author{
Muhammad Ihsan Hamdy ${ }^{1}$, Muhammad Nur ${ }^{2}$, Ahmad Mas'ari ${ }^{3}$, Fajriah Elsa Suheri ${ }^{4}$ \\ 1,2,3,4 Program Studi Teknik Industri, Fakultas Sains dan Teknologi, UIN Sultan Syarif Kasim Riau \\ Jl. HR. Soebrantas No. 155 Simpang Baru, Panam, Pekanbaru, 28293 \\ Email:muhammadihsanhamdy@gmail.com, fajelsa@gmail.com
}

\begin{abstract}
ABSTRAK
Sistem kerja yang tidak ergonomis dalam satu perusahaan seringkali kurang mendapat perhatian dari pihak manajemen perusahaan. Salah satu bagian sistem yaitu pekerja. Pekerja yang ada di suatu pabrik biasanya banyak melakukan sikap dan posisi kerja yang kurang ergonomis. Hal ini secara sadar ataupun tidak akan berpengaruh terhadap produktifitas, efisiensi dan efektivitas pekerja dalam menyelesaikannya. Posisi kerja yang dimaksud seperti postur kerja dengan aktivitas Manual Material Handling (MMH). Cidera atau kecelakaan kerja yang terjadi akibat aktivitas $\mathrm{MMH}$ ini selain merugikan pekerja secara langsung atas rasa sakit yang diderita, juga berdampak buruk bagi kinerja perusahaan yaitu penurunan produktivitas perusahaan. Penelitian ini menggunakan metode Rapid Upper Limb Assessment (RULA). RULA adalah metode yang dikembangkan dalam bidang ergonomi yang menginvestigasikan dan menilai posisi kerja yang dilakukan oleh tubuh bagian atas. PT. Asia Forestama Raya merupakan sebuah industri yang memproduksi plywood untuk ekspor maupun lokal. Dimana pada perusahaan ini masih terdapat aktivitas manual yaitu pada bagian pembuatan block. Pada penelitian ini di bagikan kuesioner Nordic Body Map untuk mengidentifikasi keluhan apa saja yang dirasakan oleh pekerja. Keluhan yang dirasakan pekerja terasa hampir pada seluruh anggota tubuh pekerja. Keluhan yang paling banyak dirasakan pekerja diantaranya adalah sakit pada punggung sebesar 47,14\%. Sedangkan sakit pada pinggang adalah sebesar 44,30\%, serta sakit pergelangan tangan kanan dan kiri masing-masing sebesar $44,17 \%$ dan $44,30 \%$. Penelitian ini bertujuan untuk mengetahui dan menganalisa kategori postur kerja dari pekerja pembuatan block di PT. Asia Forestama Raya. Dari pengolahan data yang telah dilakukan, pada posisi pertama dan kedua didapat action level 4 dengan skor akhir sebesar 7, berarti kondisi ini berbahaya sehingga pemeriksaan dan perubahan posisi kerja harus dilakukan (saat itu juga). Hal ini disebabkan postur kerja ini dilakukan dalam rentang waktu berulang sehingga dapat membahayakan pekerjanya. Sedangkan pada postur kerja ketiga dan kelima terlihat bahwa postur kerja berada pada action level 3 dengan besar skor akhir adalah 5. Dimana pada level ini diperlukan perbaikan postur kerja se-segera mungkin. Berbeda pada postur kerja keempat, didapat skor akhir sebesar 4, postur kerja ini termasuk dalam kategori action level 2 yang berarti tidak begitu membahayakan pekerjanya. Namun akan berbahaya jika dilakukan terus-menerus sehingga apabila semakin cepat dilakukan perbaikan akan lebih baik.
\end{abstract}

Kata Kunci: Manual Material Handling (MMH), Nordic Body Map, Biomekanika, RULA, dan Postur Kerja.

\section{Pendahuluan}

PT. Asia Forestama Raya merupakan sebuah perusahaan yang bergerak dibidang produksi plywood yang berlokasi di Jl. Sembilang, Kelurahan Limbungan, Kecamatan Rumbai Pesisir, Pekanbaru. Adapun masalah yang terjadi di perusahaan ini yaitu pada kegiatan pembuatan Block. Dimana pembuatan Block merupakan proses produksi plywood lokal yang proses produksinya menggunakan tenaga manual. Pada bagian produksi ini dibagi menjadi dua shift. Untuk shift 1 jam kerja mulai pukul $07.00-19.00$. Sedangkan untuk shift 2 jam kerja mulai pukul
$19.00-07.00$ dengan total jam istirahat adalah selama 2 jam.

Pada survei yang telah dilakukan, terlihat bahwa pada pekerjaan Manual Material Handling (MMH) masih banyak ditemukan pada bagian pembuatan block. Dimana pekerjaan Manual Material Handling (MMH) ini menyebabkan terasa sakit pada hampir seluruh anggota tubuh pekerja. Pembagian kuesioner NBM ini bertujuan untuk mengetahui keluhankeluhan apa saja yang dirasakan pekerja selama menjalankan pekerjaannya. Dan pada kuesioner yang telah dibagikan terhadap 70 orang pekerja, didapat keluhan yang paling banyak dirasakan diantaranya adalah sakit pada 
punggung, sakit pada pinggang, serta sakit pada pergelangan tangan kanan dan kiri.

\section{Tinjauan Pustaka}

\section{Pengertian Biomekanika}

Biomekanika adalah suatu ilmu pengetahuan yang merupakan kombinasi dari ilmu fisika (khususnya mekanika) dan teknik, berdasar pada biologi dan juga pengetahuan lingkungan.

\section{Metode RULA (Rapid Upper Limb Assesment)} Rapid Upper Limb Assesment (RULA) adalah metode yang dikembangkan alam bidang ergonomi yang menginvestigasikan dan menilai posisi kerja yang dilakukan oleh tubuh bagian atas. Dalam mempermudah penilaian postur tubuh, maka tubuh dibagi atas 2 segmen grup, yaitu grup A dan grup B (Pangaribuan, 2010).

1. Penilaian Postur Tubuh Grup A

Postur tubuh grup A terdiri atas lengan atas (upper arm), lengan bawah (lower arm), pergelangan tangan (wrist) dan putaran pergelangan tangan (wrist twist).

2. Penilaian Postur Tubuh Grup B Postur tubuh grup B terdiri atas leher (neck), batang tubuh (trunk), dan kaki (legs).

\section{Metode Penelitian}

Pengolahan data menggunakan metode RULA dengan cara memberi penilaian pada postur tubuh yang terbagi 3 segmen yaitu:

1. Penilaian Postur Tubuh Grup A

Dengan melakukan skor pengukuran derajat terhadap anggota tubuh lengan atas, lengan bawah, pergelangan tangan dan putaran pergelangan tangan pada Grup A. Kemudian nilai dari postur tubuh tersebut dimasukkan kedalam tabel postur tubuh grup A

2. Penilaian Postur Tubuh Grup B

Sama seperti pada grup A, terlebih dahulu dilakukan pengukuran skor terhadap anggota tubuh yaitu leher, batang tubuh dan kaki. Kemudian nilai dari skor postur tubuh leher, batang tubuh, dan kaki dimasukkan ke dalam Tabel untuk mengetahui skor grup B.

3. Penilaian Grand Score

Merupakan penilaian skor akhir setelah dilakukan penilaian postur tubuh Grup A dan penilaian postur tubuh Grup B.
Kemudian akan dilihat pada skor akhir berdasarkan kategori postur kerja.

\section{Hasil dan Pembahasan}

Pada pengolahan data, dilakukan pengolahan terhadap postur kerja dari 5 stasiun kerja. Terlebih dahulu dilakukan perhitungan skor A dan skor B yang nantinya dimasukkan dalam tabel grand score.

\section{Postur tubuh pertama}

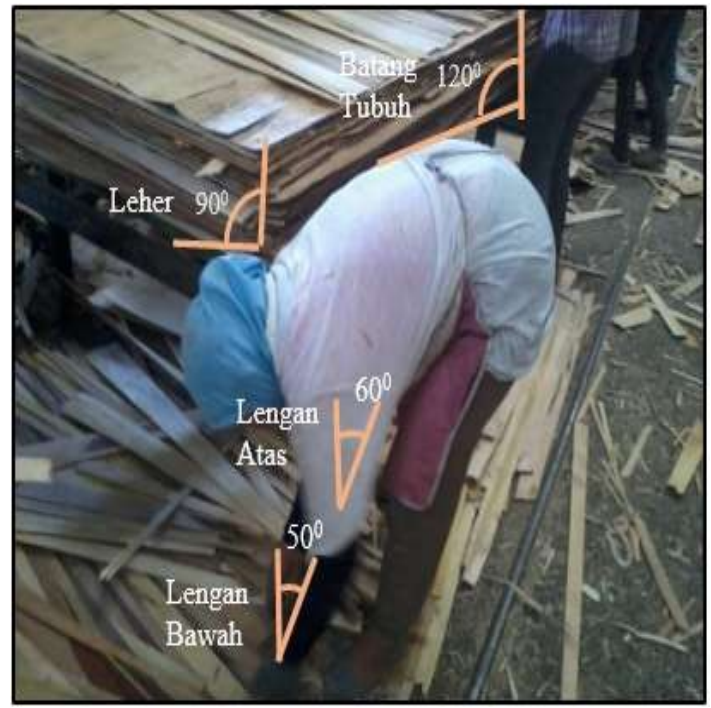

Gambar Sudut Pengukuran Metode RULA untuk Postur Tubuh Pertama

a. Penilaian postur tubuh grup A

Penilaian postur tubuh grup A terdiri atas:

1) Lengan atas (Upper arm)

Pada saat melakukan pekerjaannya, lengan atas pekerja membentuk sudut $60^{\circ}$ terhadap tubuh pekerja, dan diberi skor 3. Karena pekerjaan ini dilakukan dalam keadaan lengan bawah tertekan sehingga skor ditambahkan 1 menjadi 4.

2) Lengan bawah (Lower arm)

Pada saat melakukan pekerjaannya, lengan bawah pekerja membentuk sudut 500, maka diberi skor $=2$.

3) Pergelangan tangan (Wrist)

Pergelangan tangan membentuk sudut $20^{\circ}$ maka diberi skor $=3$.

4) Putaran pergelangan tangan (Wrist twist)

Telapak tangan tertekuk didekat dari putaran sehingga skor putaran pergelangan tangan (Wrist twist) adalah 2. 
Kemudian nilai tersebut dimasukkan kedalam tabel postur tubuh grup A seperti tampak pada tabel berikut.

Tabel Skor Grup A Postur Tubuh Pertama

\begin{tabular}{|c|c|c|c|c|c|c|c|c|c|}
\hline \multirow{2}{*}{\multicolumn{2}{|c|}{ Group A }} & \multicolumn{8}{|c|}{ Wrist } \\
\hline & & \multicolumn{2}{|c|}{1} & \multicolumn{2}{|c|}{2} & \multicolumn{2}{|c|}{3} & \multicolumn{2}{|c|}{4} \\
\hline & & \multirow{2}{*}{\multicolumn{2}{|c|}{$\begin{array}{l}\text { Wrist } \\
\text { Twist }\end{array}$}} & \multirow{2}{*}{\multicolumn{2}{|c|}{$\begin{array}{l}\text { Wrist } \\
\text { Twist }\end{array}$}} & \multirow{2}{*}{\multicolumn{2}{|c|}{$\begin{array}{l}\text { Wrist } \\
\text { Twist }\end{array}$}} & \multirow{2}{*}{\multicolumn{2}{|c|}{$\begin{array}{l}\text { Wrist } \\
\text { Twist }\end{array}$}} \\
\hline \multirow{2}{*}{$\begin{array}{l}\text { tpper } \\
\text { Arm }\end{array}$} & \multirow{2}{*}{$\begin{array}{c}\text { Lower } \\
\text { Arm }\end{array}$} & & & & & & & & \\
\hline & & 1 & 2 & 1 & 2 & 1 & 2 & 1 & 2 \\
\hline \multirow{3}{*}{1} & 1 & 1 & 2 & 2 & 2 & 2 & 3 & 3 & 3 \\
\hline & 2 & 2 & 2 & 2 & 2 & 3 & 3 & 3 & 3 \\
\hline & 3 & 2 & 3 & 2 & 3 & 3 & 3 & 4 & 4 \\
\hline \multirow{3}{*}{2} & 1 & 2 & 2 & 2 & 3 & 3 & 3 & 4 & 4 \\
\hline & 2 & 2 & 2 & 2 & 3 & 3 & 3 & 4 & 4 \\
\hline & 3 & 2 & 3 & 3 & 3 & 3 & 4 & 4 & 5 \\
\hline \multirow{3}{*}{3} & 1 & 2 & 3 & 3 & 3 & 4 & 4 & 5 & 5 \\
\hline & 2 & 2 & 3 & 3 & 3 & 4 & 4 & 5 & 5 \\
\hline & 3 & 2 & 3 & 3 & 4 & 4 & 4 & 5 & 5 \\
\hline \multirow{3}{*}{4} & 1 & 3 & 4 & 4 & 4 & 4 & 4 & 5 & 5 \\
\hline & 2 & 3 & 4 & 4 & 4 & 4 & 4 & 5 & 5 \\
\hline & 3 & 3 & 4 & 4 & 5 & 5 & 5 & 6 & 6 \\
\hline \multirow{3}{*}{5} & 1 & 5 & 5 & 5 & 5 & 5 & 6 & 6 & 7 \\
\hline & 2 & 5 & 6 & 6 & 6 & 6 & 7 & 7 & 7 \\
\hline & 3 & 6 & 6 & 6 & 7 & 7 & 7 & 7 & 8 \\
\hline \multirow{3}{*}{6} & 1 & 7 & 7 & 7 & 7 & 7 & 8 & 8 & 9 \\
\hline & 2 & 7 & 8 & 8 & 8 & 8 & $9^{m}$ & $9^{m}$ & 9 \\
\hline & 3 & 9 & 9 & 9 & 9 & 9 & 9 & 9 & 9 \\
\hline
\end{tabular}

Skor postur tubuh grup A berdasarkan tabel 4.2 adalah $=4$. Oleh karena aktivitas pekerja dilakukan secara berulang dalam rentang waktu 4 menit maka skor A ditambah 1 . Selain itu, berat beban yang diangkut adalah $3 \mathrm{~kg}$, maka skor ditambah 1. Sehingga total skor pada grup A adalah 6 .

b. Penilaian Postur Tubuh Grup B

1) Leher (neck) berada pada posisi menunduk sehingga skor untuk neck adalah 4.

2) Batang Tubuh (trunk) membentuk sudut $>600$ dengan skor $=4$.

3) Kaki (legs) berada pada posisi normal $/$ seimbang dengan skor $=1$. Penilaian postur tubuh grup B dapat dilihat pada tabel berikut.
Tabel Skor Grup B Postur Tubuh Pertama

\begin{tabular}{|c|c|c|c|c|c|c|c|c|c|c|c|c|}
\hline \multirow{3}{*}{ GrupB } & \multicolumn{12}{|c|}{ Trunk } \\
\hline & \multicolumn{2}{|c|}{1} & \multicolumn{2}{|c|}{2} & \multicolumn{2}{|c|}{3} & \multicolumn{2}{|c|}{4} & \multicolumn{2}{|c|}{5} & \multicolumn{2}{|c|}{6} \\
\hline & \multicolumn{2}{|c|}{ Legs } & \multicolumn{2}{|c|}{ Legs } & \multicolumn{2}{|c|}{ Legs } & \multicolumn{2}{|c|}{ Legs } & \multicolumn{2}{|c|}{ Legs } & \multicolumn{2}{|c|}{ Legs } \\
\hline Neck & 1 & 2 & 1 & 2 & 1 & 2 & 1 & 2 & 1 & 2 & 1 & 2 \\
\hline 1 & 1 & 3 & 2 & 3 & 3 & 4 & 5 & 5 & 6 & 6 & 7 & 7 \\
\hline 2 & 2 & 3 & 2 & 3 & 4 & 5 & 5 & 5 & 6 & 7 & 7 & 7 \\
\hline 3 & 3 & 3 & 3 & 4 & 4 & 5 & 5 & 6 & 6 & 7 & 7 & 7 \\
\hline 4 & 5 & 5 & 5 & 6 & 6 & 7 & 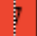 & 7 & 7 & 7 & 8 & 8 \\
\hline 5 & 7 & 7 & 7 & 7 & 7 & 8 & 8 & 8 & 8 & 8 & 8 & 8 \\
\hline 6 & 8 & 8 & 8 & 8 & 8 & 8 & 8 & 9 & 9 & 9 & 9 & 9 \\
\hline
\end{tabular}

Dikarenakan aktivitas pekerja dilakukan secara berulang dalam rentang waktu 4 menit sekali maka skor B ditambah 1. Selain itu, berat beban yang diangkut adalah $3 \mathrm{~kg}$, maka skor ditambah 1. Sehingga total skor pada grup B adalah 9.

Penilaian untuk skor akhir dapat dilihat pada tabel berikut ini. Skor akhir yang didapat pada postur tubuh pertama yaitu $=7$.

Tabel Nilai Akhir Postur Tubuh Pertama

\begin{tabular}{|c|c|c|c|c|c|c|c|c|c|}
\multirow{2}{*}{$\begin{array}{c}\text { Skor } \\
\text { Grup A }\end{array}$} & \multicolumn{7}{|c|}{ Nilai Akhir (Grand Total Score) } \\
\cline { 2 - 10 } & $\mathbf{1}$ & $\mathbf{2}$ & $\mathbf{3}$ & $\mathbf{4}$ & $\mathbf{5}$ & $\mathbf{6}$ & $\mathbf{7}$ & $\mathbf{8}$ & $\mathbf{9}$ \\
\hline $\mathbf{1}$ & 1 & 2 & 3 & 3 & 4 & 5 & 5 & 5 & 5 \\
\hline $\mathbf{2}$ & 2 & 2 & 3 & 4 & 4 & 5 & 5 & 5 & 5 \\
\hline $\mathbf{3}$ & 3 & 3 & 3 & 4 & 4 & 5 & 6 & 6 & 6 \\
\hline $\mathbf{4}$ & 3 & $\mathbf{3}$ & $\mathbf{3}$ & $\mathbf{4}$ & $\mathbf{5}$ & $\mathbf{6}$ & $\mathbf{6}$ & $\mathbf{6}$ & $\mathbf{6}$ \\
\hline $\mathbf{5}$ & 4 & 4 & 4 & 5 & 6 & 7 & 7 & 7 & 7 \\
\hline $\mathbf{6}$ & 4 & 4 & 5 & 6 & 6 & 7 & 7 & 7 & 7 \\
\hline $\mathbf{7}$ & 5 & 5 & 6 & 6 & 7 & 7 & 7 & 7 & 7 \\
\hline $\mathbf{8}$ & 5 & 5 & 6 & 7 & 7 & 7 & 7 & 7 & 7 \\
\hline $\mathbf{9}$ & 5 & 5 & 6 & 7 & 7 & 7 & 7 & 7 & 7 \\
\hline
\end{tabular}

Tabel Rekapitulasi Kategori Pengolahan Data Postur Kerja Metode RULA

\begin{tabular}{|l|l|l|l|}
\hline $\begin{array}{c}\text { Postur } \\
\text { Kerja }\end{array}$ & $\begin{array}{l}\text { Grand } \\
\text { Score }\end{array}$ & $\begin{array}{c}\text { Action } \\
\text { Level }\end{array}$ & \multicolumn{1}{|c|}{ Keterangan } \\
\hline $\begin{array}{l}\text { Postur } \\
\text { Kerja } \\
\text { Pertama }\end{array}$ & 7 & 4 & $\begin{array}{l}\text { Kondisi ini berbahaya } \\
\text { sehingga pemeriksaan } \\
\text { dan perubahan posisi } \\
\text { kerja harus dilakukan } \\
\text { (saat itu juga) }\end{array}$ \\
\hline $\begin{array}{l}\text { Postur } \\
\text { Kerja } \\
\text { Kedua }\end{array}$ & 7 & 4 & $\begin{array}{l}\text { Kondisi ini } \\
\text { berbahaya sehingga } \\
\text { pemeriksaan dan } \\
\text { perubahan posisi } \\
\text { kerja harus dilakukan } \\
\text { (saat itu juga) }\end{array}$ \\
\hline
\end{tabular}




\begin{tabular}{|l|l|l|l|}
$\begin{array}{l}\text { Postur } \\
\text { Kerja } \\
\text { Ketiga }\end{array}$ & 5 & 3 & $\begin{array}{l}\text { Kondisi ini } \\
\text { menunjukkan bahwa } \\
\text { pemeriksaan dan } \\
\text { perubahan perlu } \\
\text { segera dilakukan }\end{array}$ \\
\hline $\begin{array}{l}\text { Postur } \\
\text { Kerja } \\
\text { Keempat }\end{array}$ & 4 & 2 & $\begin{array}{l}\text { Aktivitas ini } \\
\text { diperlukan } \\
\text { pemeriksaan lanjutan } \\
\text { dan juga diperlukar } \\
\text { perubahan-perubahan }\end{array}$ \\
\hline Postur \\
Kerja \\
Kelima
\end{tabular}

\section{Kesimpulan}

Adapun kesimpulan yang dapat diambil dalam penelitian ini adalah pada posisi pertama dan kedua didapat action level 4 dengan skor akhir sebesar 7, berarti kondisi ini berbahaya sehingga pemeriksaan dan perubahan posisi kerja harus dilakukan (saat itu juga). Hal ini disebabkan postur kerja ini dilakukan dalam rentang waktu berulang sehingga dapat membahayakan pekerjanya. Sedangkan pada postur kerja ketiga dan kelima terlihat bahwa postur kerja berada pada action level 3 dengan besar skor akhir adalah 5. Dimana pada level ini diperlukan perbaikan postur kerja se-segera mungkin. Berbeda pada postur kerja keempat, didapat skor akhir sebesar 4, postur kerja ini termasuk dalam kategori action level 2 yang berarti tidak begitu membahayakan pekerjanya. Namun akan berbahaya jika dilakukan terus-menerus sehingga apabila semakin cepat dilakukan perbaikan akan lebih baik.

\section{Daftar Pustaka}

[1] Anggraini, dkk. 2012. Analisis Postur Kerja dengan Menggunakan Metode Ovako Working Analysis System (Owas) pada Stasiun Pengepakan Bandela Karet (Studi Kasus Di Pt. Riau Crumb Rubber Factory Pekanbaru). UIN Suska Riau: Pekanbaru. Jurnal Sains dan Teknologi Vol. 10 No. 1.

[2] Budiman, Edi. 2015. Perbandingan Metode Biomekanika untuk Menganalisis Postur pada Aktivitas Manual Material Handling (MMH).

[3] Manurung, Iskia Kristy. Penentuan Batas Angkut Yang Aman Bagi Pekerja Bongkar Muat Manual dengan Menggunakan Pendekatan Fisiologi dan NIOSH Lifting Index pada PT. Pelindo II. Universitas Tanjung Pura: Pontianak.
[4] Mas'idah, Eli. 2009. Analisa Manual Material Handling (MMH) dengan Menggunakan Metode Biomekanika untuk Mengidentifikasi Resiko Cidera Tulang Belakang (Musculoskeletal Disorder). Fakultas Teknologi Unissula. Jurnal Sultan Agung Vol 65. No 119. November.

[5] Muslimah, Etika. 2006. Analisis Manual Material Handling Menggunakan NIOSH Equation. Universitas Muhammadiyah Surakarta. Jurnal Ilmiah Teknik Industri Vol. 5 No. 2. Desember.

[6] Pangaribuan, Dina Meliana. 2009. Analisa Postur Kerja dengan Metode RULA pada Pegawai Bagian Pelayanan Perpustakaan USU Medan. Universitas Sumatera Utara: Medan.

[7] Siska, dkk. 2012. Analisa Posisi Kerja pada Proses Pencetakan Batu Bata Menggunakan Metode NIOSH. UIN Suska Riau: Pekanbaru. Jurnal Ilmiah Teknik Industri Vol. 11 No. 1 Juni.

[8] Sugiharto, Anthony Irawan. 2013. Analisis Perbaikan Postur dan Metode Kerja untuk Mengurangi Kelelahan Muskuloskeletal di PT. XYZ Surabaya. Universitas Pelita Harapan: Jakarta. Jurnal GEMA AKTUALITA, Vol. 2 No. 2, Desember.

[9] Sukania, I Wayan. 2014. Identifikasi Keluhan Biomekanik dan Kebutuhan Operator Proses Packing di PT X. Universitas Tarumanegara: Jakarta.

[10] Suriatmini, Septina. 2011. Tinjauan Faktor Risiko ergonomi tehadap Keluhan Muskuloskeletal pada Aktivitas Manual Handling pada Pekerja di Bagian Produksi PTMI Tahun 2010. Universitas Indonesia: Depok. 